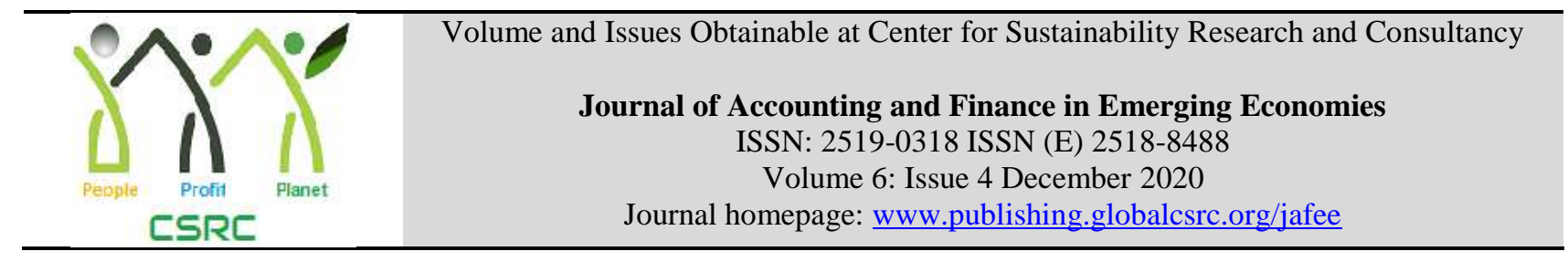

\title{
Financial Inclusion and Financial Literacy in Low Income Group in Emerging Economy
}

\author{
${ }^{1}$ Hina Affandi, ${ }^{2}$ Qaisar Ali Malik
}

${ }^{1}$ Faculty of Management Sciences, Foundation University Islamabad, Pakistan, hinaaffandi@gmail.com

${ }^{2}$ Faculty of Management Sciences, Foundation University Islamabad, Pakistan

\begin{tabular}{l} 
ARTICLE DETAILS \\
\hline History \\
Revised format: November \\
2020 \\
Available Online: December \\
2020
\end{tabular}

Keywords

Financial Institutions,

Financial Product \& Services,

Financial Literacy, Financial

Inclusion

JEL Classification:

M40, M41

\section{ABSTRACT}

Purpose: Financial institutions engage in performing imperative part in the economic development of an economy through circulation of funds that resulting in employment and fair distribution of limited resources. Financial literacy results in usage of financial product and services provided by financial institutions that lead to pervasive growth of an economy. Financial inclusion takes into loop the excluded segment of a developing country to attain the desired financial and economic outcomes. Recognizing the importance of financial inclusion, this study is executed to investigate the impact of financial literacy on financial inclusion in street vendors. Design/methodology/approach: This study was conducted in twin cities Islamabad and Rawalpindi. Snowball and purposive sampling technique has been used in this study. Primary data has been collected from street vendors through semi structure interviews and questionnaire. Participatory action research design is used in this study. Deductive approach has been used for qualitative data analysis. Findings: The results of this study found that street vendors only name financial institutions. They don't have knowledge about financial products and services provided by those financial institutions. Because of inadequate knowledge, majority of the street vendors do not use financial products and services which are available to them. A very small number of street vendors are using financial products and services. The expected outcomes of this study set a direction for policy makers of financial institutions about how to increase financial inclusion by considering the observed relations in this study. Practical Implications: The results will help policy makers in formulating effective strategies to bring into the net that excluded segment, which if included will not only improve their quality of life but also augment to the sustainability and growth of economy through financial inclusion. Originality/Value: As suggested by the recent relevant literature, the study is an attempt to identify those antecedents of financial inclusion, which has not been explored earlier in context of Pakistan, to extend the earlier findings through qualitative research method and to establish how financial inclusion can be made a success in achieving its desired outcomes in a developing economy.

(C) 2020 The authors, under a Creative Commons Attribution- 
Corresponding author's email address: hinaaffandi@gmail.com

Recommended citation: Affandi, H. \& Malik, Q. A. (2020). Financial Inclusion and Financial Literacy in Low Income Group in Emerging Economy. Journal of Accounting and Finance in Emerging Economies, 6(4), 1005-1013

\section{Introduction}

The dynamics of financial inclusion turned out to be amazingly imperative economic issue after the 2008 global crisis as it relay on the stability of financial structure in which income is not fixed that contribute to financial turmoil. In this recent era, the development of financial inclusion has engrossed the consideration by the entire world. Financial inclusion is a way in which individuals and businesses have contact to functional and reasonable financial products and services that meet their needstransactions, expenditure, investments, credit and insurance in an accountable and sustainable manner. Advancement of the financial division is an imperative part in achieving the micro practicalities of assets foundation and economic improvement of a country. Progressively more appropriate section in this association narrate to the concern of financial access which escort to financial inclusion, which revolve to superior living standards and plays an incredibly significant role in attaining sustainable growth and development.

The low-income group financial development is determined by the financial literacy regarding financial institutions and their contact to financial products and services. Consequently, a balance among financial inclusion and financial structure constancy is necessary. Financial inclusion influences the poor during two situations: aggregate growth and alteration in the division of income. Financial inclusion boost growth and decrease inequality through drip down effects. International Labour Organization has acknowledged the function of providing financial inclusion services to guarantee social safety, which recognizes it as a human right that aimed towards dropping and avoiding poverty and susceptibility throughout the life cycle (Bhandari, 2018).

Financial inclusion is an important mechanism to develop human's well being if matched with financial literacy. For low income group, financial literacy is measured to be an important requirement for a successful financial inclusion by the financial institutions. In spite of the significance of the financial literacy programmes to improve individual's financial competence, numerous limitations require to be tackle to develop outcomes. However, to conquer the objectives of financial institutions, financial literacy programmes by financial institutions is essential but, unfortunately, perceptive in this view is particularly insufficient. Financial access is a path to progress low income group welfare but deficiency of financial literacy disputes objectives set by financial institutions. Anshika and Singla (2017), evidence in their research that India has very small (24 percent) of financial literacy in contrast to BRICS (28 percent) economies and European economies (52 percent). A survey by Standards \& Poors (2014) illustrate that more than 76 percent of Indian adults be short of basic financial literacy and are incapable to comprehend the fundamental financial idea which may plays a fundamental bottleneck to financial inclusion.

In developing countries, financial exclusion is due to having low financial literacy regarding financial products and services (Atkinson \& Messy, 2013). In low income countries, motivation for saving, borrowing and employment of financial products and services influence financial inclusion (Holzmann, 2010). Financial inclusion is a system through which a developing country like Pakistan can accomplish comprehensive growth by linking the role of marginalised and the rural population section of the country with rest of the economy. There are concerns connected to financial inclusion particularly for the developing countries like Pakistan. Initially, the financial literacy is necessary, there should be programs to guarantee people can make correct financial decisions, decide financial products, which are according to their desires, and have knowledge how to use associated mediums, such as financial products and services. Numerous developing countries have been operational on financial literacy policies. There is 
need of studying the importance of financial literacy that leads to financial inclusion as prescribed by many researchers.

\section{Literature Review}

Financial Inclusion positively influence the lowest level of society that they can have investments documentation in financial institutions, contact investment from financial institutions, and amplify the aptitude of soft and hard skills. In economic growth of Indonesia, banks play an immense function to be the dynamic strength of financial inclusion actions. From an international viewpoint, this action is anticipated to maintain additional comprehensive and sustainable economic development, and can help the people wellbeing. Furthermore, financial inclusion is anticipated to sustain the financial strength as basis of firm economic progress (Widarwati, Sari \& Nurmalasari, 2019).

Kigsley (2013) has tinted the function of financial inclusion in tackling concerns such as worldwide poverty, income discrimination, under progress and wellbeing. Majority of people coming under system of financial system, their mutual impact donate to more rapid economic development. Sarma and Pais (2010) found that financial inclusion decrease the domination of casual financial institutions which are manipulative in nature and access to proper financial services raise effectiveness of the resource distribution and diminish cost of capital.

Kasman, Heuberger, and Hammond (2018) demonstrated in their research that low financial literacy is a hurdle to various Americans financial potential and welfare. Talented adults who should have financial information and financial ability to role as adults autonomously having low financial literacy (Kasman et al., 2018). Improved financial literacy can take place through authorization, necessities, principles, and state education establishment (Kasman et al., 2018). Financial inclusion endeavor to make available the recognized financial service at appropriate rate to the unbanked population as a result convenience, accessibility and consumption are imperative feature to understand financial inclusion (Pal and Vaidya, 2011; Sarma, 2012, Kumar, 2013).

Financial inclusion is vital for escalating the poor's admittance to financial services is repeatedly measured as valuable mean that can facilitate reduction in poverty and income disproportion (Park and Mercado, 2018). Admittance to a variety of services and mechanism for example discount, credit, insurance and pensions afar financial dealings is crucial social hold for a person that leads to numerous transformative impact on person's life (Gitaharie, Soelistianingsih \& Djutaharta, 2018; Smyzcek and Matysiewicz, 2014; Zhu and Walker, 2018). As a result better access to bank deposits can optimize deposit financial maintenance in banking subsequently maintain financial stability of complete financial system (Han \& Melecky, 2013).

In recent years, financial literacy has gained a lot of attention and growth in a number of countries. The reason for this growth is due to difficulties come up in vibrant financial system that necessitates financial customers to more aggressively formulate financial alternatives and assessments (Lusardi \& Mitchell, 2011). Sen's Capability Approach has applied to this research that believes that all categories of literacy are important for human development (HD) (Gasper, 2002). Financial literacy helps individuals to use their skills and knowledge that is essential for them to use financial products and services to get better their financial health and it will helps in creating financial inclusion (Braunstein \& Welch, 2002). Lack of financial literacy is major reason of low use and demand of formal financial products and services (Gine and Yang, 2009).

Numerous financial products and services presented by financial institutions and becoming complex without growth of financial literacy level between the numerous clusters of the society (Lyons, 2005). The development of consumer financial market that is providing multiple financial products and services are effecting financial decisions of an individual's (West, 2012). For using these financial products and services, there is need of financial literacy that will create as well as enhance financial inclusion. 
Several studies (Lusardi \& Mitchell, 2013; Atkinson \& Messy, 2011; Atkinson \& Messy, 2012) in this regard argued that number of potential financial customers due to having lack of related concept, knowledge and skills that is required to facilitate their financial preferences and decisions unable to use these financial products and services which results in low financial inclusion and unable to improve quality of life and wellbeing.

Financial literacy improves the poor's financial decision making along with understanding of financial matters and financial options attached with fundamental financial skills (Cohen \& Nelson, 2011). A study conducted in Indonesia, where financial literacy program conducted to educate unbanked households regarding saving account to those who don't have financial knowledge (Cole et al., 2011). Its outcome was not only increase in their financial skills but also authorize them utilized their responsibilities and rights in the consumer protection equation. Trainings regarding financial skills to poor households of developing economies facilitate them to choose saving plans offered by financial institutions (Holzmann, 2010). Lack of financial literacy in developing economies mainly in poor households is major problem in generating financial inclusion (Thorat, 2007). This leads to financial exclusion of the poor (Agarwal, 2008). Those poor households who are unfamiliar with financial products and financial services will not use those (Cole et al., 2010). Well informed poor households can assess financial products and services to create well informed decision as a result they gain supreme utility (Lusardi, 2009). It also contributes to proficient allotment of economic resources and superior financial potency (Lusardi \& Tufano, 2009).

In fact, financial literacy can facilitate poor households to realize the saving rationale (Holzmann, 2010). Ardic et al. (2011) described in his study that financial literacy decrease asymmetric information due to having knowledge regarding financial products and services offered in the financial market. Financial knowledge considerably develops essential understanding of financial options and approach towards financial products and services and makes appropriate financial decision (Carpena et al., 2011), thus persuade evade substandard financial products and services (Braunstein and Welch, 2002).

Low financial literacy results in low pace of retirement plans, lesser involvement in stock exchange, pay higher charges for employing financial products and services and having high debt (Lusardi \& Mitchell, 2014). Many nationals in economy have less formal product and services offered in financial markets, lack of training on financial aspects and involvement in developing countries (Xu \& Zia, 2012). Jappelli (2010) described in his study that training related to financial literacy enhance the financial understanding which influence financial behavior of poor households. Having good financial knowledge in poor households enhance their ability to manage their budget and save money for old age (Holzmann, 2010). Financial literacy facilitates many financial behaviors for example investments, insurance, plan for retirement, participation in financial markets, access of bank accounts, savings, and other financial practices (Braunstein \& Welch, 2002).

\section{Methodology}

A possible source of data in this study is primary data. Primary data has been collected through semi structured interview and questionnaire. Qualitative data has been utilized for this research. Therefore qualitative research method has been used in this study. The units of analysis for the study consist of street vendors residing in twin cities Islamabad and Rawalpindi, Pakistan. A total sample of 89 street venders covered under this study. Street venders actively participated in interview. Seven street venders refused for interviews. Furthermore, snow ball and purposive sampling technique has been used in selecting the sample. Participatory action research design is used in this study. Deductive approach has been used for qualitative data analysis. A saturation criterion was adopted to finish process of data collection. The collected data was analyzed through SPSS and content analysis.

This research used a semi-structured questionnaire, which was formulated according to guiding principles recommended by Sekaran (2000). The semi-structured questionnaire has both open-ended and 
closed-ended questions to explore the variables under this study conducted in Pakistan. Financial literacy measured through knowledge of financial planning, saving behavior, financial knowledge and financial concepts and financial inclusion measured through access and experience through financial service (Clarka et al., 2018). Individual street vendor characteristics includes age, gender, marital status and education level, product they are selling (edible, clothes, shoes, cosmetics, others) and weekly sales (1,000-15,000) (Irankunda \& Bergeijk, 2019).

\section{Analysis \& Discussion}

Individual characteristics act as important determinants of financial inclusion (Zins and Weill, 2016). Table 1 shows descriptive statistics for individual street vendor characteristics, product and weekly sales. This table described the minimum, maximum, mean, standard deviation and variance for age, gender, marital status, education, business type and weekly income. Table 2 described frequency of use by individual street vendor characteristics, product and weekly sales.

Table 1: Descriptive Statistics for Individual Street Vendor Characteristics, Product and Weekly Sales (N=89)

\begin{tabular}{|l|c|c|c|c|c|}
\hline & Minimum & Maximum & Mean & Std. Deviation & Variance \\
\hline Age & 1 & 4 & 3.24 & .826 & .682 \\
\hline Gender & 1 & 1 & 1.00 & .000 & .000 \\
\hline Marital Status & 1 & 3 & 1.31 & .556 & .309 \\
\hline Education & 1 & 4 & 2.30 & .922 & .850 \\
\hline Business Type & 1 & 5 & 3.09 & 1.557 & 2.424 \\
\hline Weekly Income & 1 & 4 & 2.47 & 1.129 & 1.275 \\
\hline
\end{tabular}

Frequency for age includes $3.4 \%$ of the sample ranges from 20 and below, $14.6 \%$ of the sample ranges from 21 to 30 years, $37.1 \%$ of the sample ranges from 31 to 40 and $44.9 \%$ of the sample ranges from 41 to 50 . Frequency for gender includes $100 \%$ male. $73 \%$ of the sample were married, $22.5 \%$ of the sample were unmarried and $4.5 \%$ of the sample were separated. Education level include $20.2 \%$ of the sample were included in primary, $40.4 \%$ of the sample were included in middle, $28.1 \%$ included in matric and $11.2 \%$ were include in FA/FSc/other. Business type includes edible $22.5 \%$, clothes $18 \%$, shoes $18 \%$, cosmetics $11.2 \%$, and other business like kitchen utensils etc 30.3\%. 22.5\% of the sample earn from Rs 5,000 to $10000,36 \%$ earn from 11,000 to $15000,13.5 \%$ earn from 16,000 to 20,000 and others earn less than 5000 was $28.1 \%$.

Table 2: Frequency of Use by Individual Street Vendor Characteristics, Product and Weekly Sales (N=89)

\begin{tabular}{|l|l|c|c|}
\hline $\begin{array}{c}\text { Individual Street } \\
\text { Vendors Characteristics }\end{array}$ & \multicolumn{1}{|c|}{ Categories } & Frequency & Percent \\
\hline \multirow{4}{*}{ Age } & $\mathbf{2 0 ~ \& ~ B e l o w ~}$ & 3 & 3.4 \\
\cline { 2 - 4 } & $\mathbf{2 1 - 3 0}$ & 13 & 14.6 \\
\cline { 2 - 4 } & $\mathbf{3 1 - 4 0}$ & 33 & 37.1 \\
\cline { 2 - 4 } & $\mathbf{4 1 - 5 0}$ & 40 & 44.9 \\
\hline \multirow{3}{*}{ Gender } & Male & 89 & 100.0 \\
\cline { 2 - 4 } & Female & 0 & 0 \\
\hline \multirow{5}{*}{ Education } & Married & 65 & 73.0 \\
\cline { 2 - 4 } & Unmarried & 20 & 22.5 \\
\cline { 2 - 4 } & Separated & 4 & 4.5 \\
\hline \multirow{5}{*}{ Business Type } & Primary & 18 & 20.2 \\
\cline { 2 - 4 } & Middle & 36 & 40.4 \\
\cline { 2 - 4 } & Matric & 25 & 28.1 \\
\cline { 2 - 4 } & FA/FSC/other & 10 & 11.2 \\
\hline \multirow{3}{*}{ Weekly Income } & Edibles & 20 & 22.5 \\
\cline { 2 - 4 } & Clothes & 16 & 18.0 \\
\cline { 2 - 4 } & Shoes & 16 & 18.0 \\
\cline { 2 - 4 } & Cosmetics & 10 & 30.3 \\
\cline { 2 - 4 } & Other & 27 & 22.5 \\
\cline { 2 - 4 } & $\mathbf{5 , 0 0 0 - 1 0 , 0 0 0}$ & 20 & 36.0 \\
\hline
\end{tabular}




\begin{tabular}{|l|l|l|l|}
\hline & $\mathbf{1 6 , 0 0 0 - 2 0 , 0 0 0}$ & 12 & 13.5 \\
\cline { 2 - 4 } & Other & 25 & 28.1 \\
\hline
\end{tabular}

Street vendors do financial planning according to their income. They save money by limiting their budget through fewer fulfillments of their needs or through committee. Whatever they save majority of them keep that money at home. When they need money, majority of them borrow from friends and family members. Very less number of them borrows from bank.

The result found in this study that only two of the street vendors from whole sample use financial products and services. Majority of them don't have bank accounts and don't have knowledge about financial institutions. They only name Bank (financial institution), but they don't have knowledge about their financial products and services and don't know about interest rate. Majority of street vendors do not use financial products and services which are available to them. A very small number of street vendors are using financial products and services.

Higher financial literacy leads to more financial inclusion (Doi et al., 2014; Jamison et al., 2014). Therefore, financial literacy contributes to better financial decision making (Grohmann et al., 2018). The results of this study showed that there is lack financial literacy which demonstrates that there is lapse on the behalf of financial institutions and economic stakeholders that they don't organize awareness programs. As a result of which majority of people are financially excluded. Financial institutions play an important role in circulation of funds that helps in creating employment and fair distribution of scare resources. Due to lack of financial literacy programs by the financial institutions underprivileged segment of the society unable to access the financial products and services which are available to them. Whatever they save that money is not productive because they are keeping it at home and won't be investing to increase their income. Financial literacy training programs offer information regarding financial planning, concepts, and banking services, increasing street vendors' financial and money managing abilities. The results of this study supported by Sen's (1999) capacities approach to development by endorsing adolescents' financial competence (Johnson \& Sherraden, 2007). This approach involves not only financial literacy and skills, but also access to and understanding with financial products and financial services.

\section{Conclusion}

Therefore, financial literacy is necessary, there should be programs to guarantee people can make correct financial decisions, decide financial products, which are according to their desires, and have knowledge how to use associated mediums, such as financial products and services. Numerous developing countries have been operational on financial literacy policies. There is need of recognizing the importance of financial literacy by the financial institutions that leads to financial inclusion. This study concludes that majority of street vendors don't have bank accounts and they don't even use financial products and financial services. The reason behind these financially excluded street vendors is lack of financial literacy that is lack of knowledge regarding financial products and services offered by financial institutions.

Financial institutions play an important role in promoting financial literacy. In Pakistan, financial institution's role is lacking in promoting their financial products and financial services. Financial institutions should schedule financial literacy programs on regular basis. These programs will help in creating awareness regarding financial products and services offered by financial institutions. As a result, vulnerable or underserved segment will use financial products and services; consequently they will be financially included and improve their financial wellbeing. Not limited to this, it will also helps in poverty reduction. 


\section{Limitation of Study and Future Research Directions}

There are certain limitations of this study due to financial and time constraints. In future, researchers must study mediating variables like financial self-efficacy, financial advice etc and moderating variable like social networks, institutional framework etc in existing study. This study is based on interviews, for triangulation purpose both qualitative and quantitative data must be incorporated in future research.

\section{Reference}

Agarwal, R. (2007), "100 \% financial inclusion: a challenging task ahead", paper presented at the Conference on Global Competitiveness of Indian Corporate.

Anshika \& Singla, A. (2017), "Financial literacy in India- an Appraisal", International Journal of Science, Technology and Management, (1).

Ardic, O.P., Heimann, M. and Mylenko, N. (2011), "Access to financial services and the financial inclusion agenda around the world", A Cross-Country Analysis with a New Data Set, The World Bank Financial and Private Sector Development Consultative Group to Assist the Poor, January, WPS5537

Atkinson, A. \& Messy, F. A. (2011). Assessing financial literacy in 12 countries: an OECD/INFE international pilot exercise. Journal of Pension Economics and Finance, 10, 657-665.

Atkinson, A. \& Messy, F.-A. (2012). Measuring Financial Literacy. OECD Working Papers on Finance, Insurance and Private Pension.

Atkinson, A. and F. Messy (2013), "Promoting Financial Inclusion through Financial Education: OECD/INFE Evidence, Policies and Practice", OECD Working Papers on Finance, Insurance and Private Pensions, No. 34, OECD Publishing. http://dx.doi.org/10.1787/5k3xz6m88smp-en.

Bhandari, B.S. (2018). Life Insurance - Social Security \& Financial Inclusion, Bimaquest, Vol. 18 Issue 2, May 2018.

Braunstein, S. \& Welch, C. (2002), "Financial literacy: an overview of practice, research, and policy", Federal Reserve Bulletin, Washington DC.

Braunstein, S. and Welch, C. (2002), "Financial literacy: an overview of practice, research, and policy", Federal Reserve Bulletin, Washington DC.

Carpena, F., Cole, S., Shapiro, J. and Zia, B. (2011), "Unpacking the causal chain of financial literacy", Policy Research Working Paper No. 5798/e, World Bank Development Research Group, Washington DC.

Clarka, S., Paula, M., Aryeeteyb, R., \& Marquisc, G. (2018). An assets-based approach to promoting girls' financial literacy, savings, and education. Journal of Adolescence, 68, 94-104.

Cohen, M. and Nelson, C. (2011), "Financial literacy: a step for clients towards financial inclusion", draft paper, World Bank, Washington, DC.

Cole, S., Sampson, T. and Zia, B. (2011), "Price or knowledge? What drives demand for financial services in emerging markets?", The Journal of Finance, Vol. 66 No. 6, pp. 1933-1967.

Doi, Y., McKenzie, D., \& Zia, B. (2014). Who you train matters: Identifying combined effects of financial education on migrant households. Journal of Development Economics, 109, 39-55.

Gasper, D. (2002) Is Sen's Capability Approach an Adequate Basis for Considering Human Development?, Review of Political Economy, 14:4, 435-461, DOI: 10.1080/0953825022000009898

Giné, X. \& Yang, D. (2009). Insurance, credit, and technology adoption: Field experimental evidencefrom Malawi. Journal of development Economics, 89, 1-11.

Gitaharie, T., Soelistianingsih, L., and Djutaharta, T.(2018), Financial inclusion: The impacts of bank loans on household welfare, in Competition and Cooperation in Economics and Business - Gani et al. (Eds) 2018 Taylor \& Francis Group, London, ISBN 978-1-138-62666-9

Grohmann, A., Klühs, T., \& Menkhoff, L. (2018). Does financial literacy improve financial inclusion? Cross country evidence. World Development, 84-96.

Han, R., \& Melecky, M. (2013). Financial Inclusion for Stability : Access to Bank Deposits and The Deposits Growth during the Global Financial Crisis. MPRA Paper. No. 48339.

Holzmann, R. (2010), "Bringing financial literacy and education to low and middle income countries: 
the need to review, adjust, and extend current wisdom”, World Bank, IZA and CES, Washington DC, available at: http://erepository.uonbi.ac.ke:8080/xmlui/handle/123456789/9897 (accessed June, 2012).

Irankunda, D., \& Bergeijk, P.A.G.V. (2019). Financial Inclusion of Urban Street Vendors in Kigali. Journal of African Business.

Jamison, J.C., Karlan, D., Zinman, J. (2014). Financial education and access to savings accounts: Complements or substitutes? Evidence from Ugandan Youth Clubs. NBER Working Paper, No. 20135.

Jappelli, T. (2010), "Economic literacy: an international comparison", The Economic Journal, Vol. 120 No. 548, pp. 429-451.

Johnson, E., \& Sherraden, M. S. (2007). From financial literacy to financial capability among youth. Journal of Sociology \& Social Welfare, 34, 119

Kasman, M., Heuberger, B., \& Hammond, R. (2018). A review of large scale youth financial literacy education policies and programs. The Brookings Institution.

Kigsley, C.M. (2013), "A Global View on Financial Inclusion: Perspectives from a Frontier Market", The Guardian, Cited by Babajide, Adegboye and Omankhanlen (2015).

Kumar, N. (2013), "Financial Inclusion and Its Determinants: Evidence From India", Journal of Financial Economic Policy, 5 (1).

Lusardi, A. \& Mitchell, O. S. (2011). Financial literacy and planning: Implications for retirement wellbeing. National Bureau of Economic Research.

Lusardi, A. \& Mitchell, O. S. (2013). The economic importance of financial literacy: Theory and evidence. National Bureau of Economic Research.

Lusardi, A. and Mitchell, O., (2014). "The Economic Importance of Financial Literacy: Theory and Evidence." Journal of Economic Literature, 52(1), 5-44. Available at: http://dx.doi.org/10.1257/jel.52.1.5

Lusardi, A. and Tufano, P. (2009), "Debt literacy, financial experiences, and over indebtedness", Working Paper Series No. 14808, National Bureau of Economic Research.

Lyons, A. C. (2005). Financial education and program evaluation: Challenges and potentials for financial professionals. Journal of Personal Finance, 4, 56-68.

Pal, R. and Vidya, R. (2011), "Outreach of Banking Services Across Indian States, 1981-2007: Converging or Diverging?", India Development Report, 2011, Oxford University Press.

Park, CY, \& Mercado (2018), Financial Inclusion, Poverty, and Income Inequality, The Singapore Economic Review, Vol. 63, No. 1 (2018) 185-206

S\&P survey (2014), "More than 70 percent Indians fare badly in financial literacy", Retrieved from http://www.livemint.com/Money/219bZsVo7eempRU9yLvPAL/SP-survey-More-than-70Indians-farebadly-in-financial-li.html

Sarma (2012), "Index of Financial Inclusion - A Measure of Financial Sector Inclusiveness", Berlin Working Papers on Money, Finance, Trade and Development Working Paper No. 07/2012.

Sarma, M. \& Pais, J. (2010), "Financial Inclusion and Development: A Cross Country Analysis", Indian Council for Research on International Economic Relations, pp 1-28.

Sen, A. (1999). Development as freedom. Oxford: Oxford University Press.

Smyczek, S., and Matysiewicz, J.(2014), Financial Exclusion as Barrier to Socio-Economic Development of the Baltic Sea Region, Journal of Economics \& Management, 2014 (15) 80-104 The Process of Theory.

Thorat, U. (2007), "Taking banking services to the common man - financial inclusion", Deputy Governor, Reserve Bank of India at the HMT-DFID Financial Inclusion Conference, Whitehall Place, London, June 19.

West, J. (2012). Financial literacy education and behaviour unhinged: Combating bias and poor product design. International Journal of Consumer Studies, 36, 523-530.

Widarwati, E., Sari, P., \& Nurmalasari, N. (2019). Role of Financial Inclusion to Stability: The Case of Indonesia's Sharia Banking. HOLISTICA Vol 10, Issue 1, 2019, pp. 7-15.

$\mathrm{Xu}$, L. and Zia, B. (2012), "Financial literacy around the world: an overview of the evidence with 
practical suggestions for the way forward”, Policy Research Working Paper No. 6107, The World Bank, Washington, DC.

Zhu, H. and Walker, A.C. (2018) orcid.org/0000-0002-3169-2738 Pensions and social inclusion in an ageing China. Ageing \& Society. ISSN 0144-686X

Zins, A., \& Weill, L. (2016). The determinants of financial inclusion in Africa. Review of Development Finance, 6(1), 46-57. 